\title{
Chromosomal Aberrations in Early Embryos of Weatherfish (Misgurnus fossilis L.) Exposed to Crude Cyanobacterial Extract and Semipurified Compound of Microcystins - a Pilot Study
}

\author{
M. PALÍKOVÁ ${ }^{1}$, M. RÁBOVÁ ${ }^{2}$, R. KREJČÍ ${ }^{3}$, S. NAVRÁTIL ${ }^{1}$, L. BLÁHA ${ }^{4}$ \\ ${ }^{1}$ Department of Veterinary Ecology and Environmental Protection, Faculty of Veterinary Hygiene and Ecology \\ University of Veterinary and Pharmaceutical Sciences, Brno, Czech Republic \\ ${ }^{2}$ Institute of Animal Physiology and Genetics, Laboratory of Fish Genetics, Academy of Sciences \\ of the Czech Republic, Liběchov, Czech Republic \\ ${ }^{3}$ Department of Fishery and Hydrobiology, Mendel's Agricultural and Forestry University, Brno, \\ Czech Republic \\ ${ }^{4}$ Center for Cyanobacteria and their Toxins (Institute of Botany, Czech Academy of Sciences; RECETOX, \\ Masaryk University in Brno), Brno, Czech Republic \\ Received January 18, 2007 \\ Accepted June 5, 2007
}

\begin{abstract}
Palíková M., M. Rábová, R. Krejčí, S. Navrátil, L. Bláha: Chromosomal Aberrations in Early Embryos of Weatherfish (Misgurnus fossilis L.) Exposed to Crude Cyanobacterial Extract and Semipurified Compound of Microcystins - a Pilot Study. Acta Vet. Brno 2007, 76: S55-S60.

The genotoxicity of semipurified compound of microcystins and crude extract of cyanobacteria was analyzed and assessed using detection of chromosomal aberrations in early life stages of weatherfish. For 96 hours, weatherfish eggs at an eye spot stage were exposed to semipurified compound of microcystins (MC-LR: $\Sigma M C=1: 2.6$ ) and crude cyanobacterial extract (MC-LR: $\Sigma \mathrm{MC}=1: 2.1)$ both at doses of 130,50 and $13 \mu \mathrm{g} \cdot \mathrm{l}^{-1}$. Hatching time in individual groups and aberrations in the behaviour of hatched specimens were recorded. Cumulative mortality and the proportion of deformed specimens were determined; materials for histological and cytogenetic screening were simultaneously sampled. Cumulative mortality (28 and 26\%, respectively) increased after the application of higher doses $\left(130\right.$ and $\left.50 \mu \mathrm{g} \cdot \mathrm{l}^{-1}\right)$ of crude cyanobacterial extract $(p \leq 0.05)$. In these groups, hatched embryos showed reduced agility and stayed in clusters and in the group with the highest dose of crude cyanobacterial extract white spots on yolk sacks appeared. Cytogenetic screening revealed both chromatid (gaps) and chromosomal aberrations (rings, dicentrics), percentage of which increased with the increased concentration of microcystins and the higher doses of crude cyanobacterial extract. The highest number of aberrant metaphases was recorded after the application of the highest concentrations of cyanobacterial extract and microcystin $(p \leq 0.05)$. Embryo mortality was affected especially by crude cyanobacterial extract, therefore other toxic elements than microcystins present in the extract were probably involved.
\end{abstract}

Water bloom, cyanobacteria, mortality, genotoxicity, loach model

Crude extract of cyanobacteria as well as cyanobacterial toxins themselves may act genotoxically. A number of authors dealt with genotoxicity of cyanotoxins, for instance in vitro studies on mammalian cell lines (Zhan et al. 2004; Rao et al. 1998; Humpage et al. 2000; Žegura et al. 2003; Fessard and Bernard 2003, Lankoff et al. 2003; Lankoff et al. 2004; Lankoff et al. 2006), in bacterial tests of genotoxicity (Mankiewicz et al. 2002; Ding et al. 1999) and in vivo especially with experiments using mice and brownrats (Rao et al. 1998; Rao and Bhattacharya 1996; Shen et al. 2002; Bouaïcha et al. 2005). Genotoxic effect has been recorded for microcystin LR causing DNA damage and fragmentation. The impact of microcystin LR on early developmental stages of Korean mud loach (Misgurnus mizolepis) was discussed by Liu et al. (2002) who attempted to find a difference in the sensitivity of fish eggs and larvae to microcystin LR. However, genotoxic effect of cyanotoxins to early developmental fish stages that can be directly

Phone: +420541562821

Fax: +420 541562654

e-mail: palikovam@vfu.cz

http://www.vfu.cz/acta-vet/actavet.htm 
exposed to blue green algae in water environment remains largely unknown. Though e.g. Hayashi et al. (1998), Hose and Brown (1998), Amanuma et al. (2000), Diekmann et al. (2004) studied genotoxic effects of pollutants to early developmental fish stages, these studies did not include effects of cyanotoxins.

In this pilot study we examined the possible genotoxic effect of microcystins and crude extract of cyanobacteria using detection of chromosomal aberrations in the early life stages of weatherfish. As a model fish species, the weatherfish (Misgurnus fossilis) was chosen due to its habitat preference to stagnant, largely anoxic water bodies where blue green algae bloom frequently.

\section{Materials and Methods}

Material and fish keeping

Weatherfish eggs were obtained from the fishery farm at Pohořelice, Moravia, Danube R. basin, Czech Republic. Seven groups, each with 100 fish eyed eggs were used in the experiment. Each group was incubated separately in a glass vessel containing $100 \mathrm{ml}$ water for dilution mixed according to the Czech State Norm EN ISO 7346-2. Water exchange was made using a semistatic method every 8 hours. Embryos and fish eggs were transferred by means of a fine sieve. A thermostat set at $19.5 \pm 0.3{ }^{\circ} \mathrm{C}$ maintained media temperature. Water $\mathrm{pH}$ ranged from 8.1 - 8.4. Photoperiod was made up of 16 hours of light and 8 hours of darkness. The amount of dissolved oxygen ranged from 60 to $95 \%$.

Chemical treatment

Semipurified compound of microcystins: microcystins were isolated from the natural cyanobacterial water bloom (dominated by Microcystis aeruginosa, collected in summer 2003 at Nové Mlýny reservoir, Moravia, Czech Republic) using repeated extraction with 50\% methanol and partial purification with solid-phase extraction on ODS cartridge (SepPak 35cc $10 \mathrm{~g} \mathrm{C}-18$ cartridge, Waters, Millford, MA, USA). Final extract contained three dominant microcystins (MCs) variants MC-LR, -RR, -YR (HPLC purity of total MCs at $238 \mathrm{~nm}$ was $75 \%$ ). Semipurified microcystins were aliquoted and stored at $-18{ }^{\circ} \mathrm{C}$.

Cyanobacterial extract: After thawing, biomass concentration was adjusted to $6 \mathrm{~g}$ of dry weight per litre by dilution with distilled water. Complex fresh cyanobacterial biomass was homogenized by sonication on magnetic stirrer using ultrasonic probe Bandelin Sonoplus HD2070 (15 min, cycle 0.9, 100\% power). After centrifugation (15 min, $2800 \mathrm{~g}$ ), supernatant was separated, refilled with distilled water to original volume before centrifugation and stored frozen.

Embryo treatment

Semipurified compound of microcystins (MC-LR, MC-YR, MC-RR = 1:0.6:2) at doses of 130, 50 and $13 \mu \mathrm{g} \cdot \mathrm{l}^{-1}$ were applied to three groups (labelled as MC 130, MC 50, MC 13). Cyanobacterial extract (MC-LR: $\Sigma M C=$ 1:2.1) with microcystins at doses of $130,50,13 \mu \mathrm{g} \cdot \mathrm{l}^{-1}$ was applied to other three groups (labelled as E 130, E 50, E 13). The seventh group was a control. The experiment lasted 4 days.

Data sampling

Throughout the experiment the time of hatching in individual groups and aberrations in the behaviour of the hatched specimens were recorded. Cumulative mortality and the number of deformed specimens were determined. Samples for histological examination were processed by a classical method, sealed in paraplast and the $4 \mu \mathrm{m}$ histological sections were subsequently clearly coloured by haematoxylin-eosin (HE).

Cytogenetic analysis

The specimens were treated with $0.02 \%$ colchicin for 4 hours. Then they were sacrificed by an overdose of anaestethic solution, divided in groups of ten, and a cell suspension was made using a stainless steel mesh on a Petri dish. $0.075 \mathrm{M}$ KCI hypotonic solution was applied for $50 \mathrm{~min}$. Then a cell suspension was prefixed by cold fixative (3:1 methanol and acetic acid) for $10 \mathrm{~min}$ and cell suspension centrifuged. The fixative was exchanged 3 times. The cell suspension was dropped onto cleaned slides, air-dried and stained by $5 \%$ solution of Giemsa dye $(\mathrm{pH}=7)$.

Statistical evaluation

The cumulative mortality and numbers of deformed specimen and chromosomal aberrations were statistically analysed by the $\chi^{2}$-test using the STAT plus software (Matoušková et al. 1992).

\section{Results}

The first hatched specimens were recorded in the control group within 50 hours after fertilization. In the $52^{\text {nd }}$ hour after fertilization, $15-27 \%$ of specimens were already hatched in all groups except the highest concentration of cyanobacterial extract (group E 130) where only 5 specimens were hatched. Ninety per cent of the specimens were hatched 
within 66 hours after fertilization. The increase of cumulative mortality (28 and 26\%) occurred especially after the application of higher doses of cyanobacterial extract (E 130 and $\mathrm{E} 50$, respectively), compared with the control group $(p \leq 0.01)$. Similar effects were also observed in the groups exposed to microcystins ( $p \leq 0.01$ in MC 50; $p \leq 0.05$ in MC 130). After 40 hours of exposure, these groups showed reduced agility of hatched embryos that stayed in a cluster, white spots on yolk sacks appeared in group E 130 after 56 hours. Histological examination did not reveal any pathological-anatomical changes in the examined embryos.

Standard metaphases and karyotype of control specimen are shown in Figs 1 and 2 (Plates I, II). Cytogenetic screening revealed both chromatid (gaps) and chromosomal (rings and dicentrics; Figs 3 and 4, Plates III, IV) aberrations. The number of aberrations seemed to increase with increasing concentrations of microcystins and with higher doses of cyanobacterial extract. The highest number of aberrant metaphases was recorded after the exposure to the highest doses of cyanobacterial extract as well as microcystins $(p \leq 0.05)$. Summary of cytogenetic screening of chromosomal abnormalities is shown in Table 1.

Table 1. Chromosomal aberrations (* means statistic significance at $p \leq 0.05 ; \mathrm{n}=$ number of metaphases)

\begin{tabular}{|c|c|c|c|}
\hline Group & $\mathrm{n}$ & metaphases with chromosomal abnormalities (\%) & types of aberrations \\
\hline MC 130 & 11 & $73^{*}$ & dicentric $6 \times$, ring $2 \times$ \\
\hline MC 50 & 9 & 33 & dicentric, ring $2 \times$ \\
\hline MC 13 & 8 & 25 & dicentric, ring \\
\hline E 130 & 5 & $80^{*}$ & dicentric $2 \times$, ring $2 \times$ \\
\hline E 50 & 10 & 30 & dicentric $3 \times$ \\
\hline E 13 & 8 & 38 & dicentric $2 \times$, ring \\
\hline control & 7 & 0 & - \\
\hline
\end{tabular}

\section{Discussion}

Higher toxicity of cyanobacterial extract (as compared to pure microcystins) has often been described. For example, Best et al. (2001) observed significant increase of cardiac output in brown trout (Salmo trutta L.) in response to cyanobacterial extracts while no change was observed after exposure to purified MC-LR. Stronger effects of cyanobacterial crude extracts than pure toxins were also demonstrated in tests with microalgae (Scenedesmus armatus), macrophyte (Ceratophyllum demersum), intervertebrate (Chaoborus crystallinus) as well as fish eggs (Danio rerio) by Pietsch et al. (2001). Further, Liu et al. (2002) described lower sensitivity of juvenile loach specimen (Misgurnus mizolepis) when compared with embryonic and larval stages. For juvenile stages authors reported LC50 of $593.3 \mathrm{mg} \cdot \mathrm{l}^{-1}$ for microcystin LR in a subacute 7 days exposure, LC50 of $164.3 \mathrm{mg} \cdot \mathrm{l}^{-1}$ was observed for embryonic stages exposed to MC-LR after hatching. Our experiments did not show significantly increased mortality after the application of microcystins as compared with the control group (14\% mortality in the highest microcystins dose), which might eventually be caused by shorter exposure time (4 days vs. 7 days). The significant increase of cumulative mortality (28 and 26\%) occurred especially after the application of higher doses of cyanobacterial extract.

Weatherfish from the Danube basin has a normal number of chromosomes $2 \mathrm{n}=100$ (Ene and Suciu 2000, unpublished data), although some data indicate the presence of specimen with $2 \mathrm{n}=50$ (Ráb et al. 2006). Rao et al. (1998) described DNA lesion in vivo in mice: cell free extract of Mycrocystis aeruginosa induced dose and time dependent DNA fragmentation in mouse liver. Mankiewicz et al. (2002) described genotoxicity of microcystin-LR and 12 cyanobacterial extracts containing microcystins from Polish water 
reservoirs with a different content of microcystins. Authors observed genotoxic effects of cyanobacteria in assays with both prokaryotic and eukaryotic cells but bacterial cells seem to be less sensitive. Likewise, microcystin-LR showed less pronounced genotoxic effect in human lymphocytes when compared with the complex extracts (Mankiewicz et al. 2002). Lankoff et al. (2004) observed no effect on the frequences of chromosomal aberrations in lymphocytes and the same group (Lankoff et al. 2003) showed an increase in polyploid and aberrant mitotic figures in vitro in CHO-K1 cells. In our experiments, the percentage of chromosomal abnormalities, in particular concentrations, was similar after the application of a semipurified compound of microcystins as well as after the exposure to cyanobacterial extract (containing the same levels of microcystins). It seems that microcystins were the major contributors to observed genotoxic changes, and that other components present in the tested complex extract had minor role.

Chromosomal aberrations selectively count only the primary DNA lesions that are not repaired in the cell. Some mutations have dominant effects and produce immediate alterations, other have recessive effects (Al-Sabti 1991). Assessment of chromosomal aberrations in early life stages of fish encounters a number of problems. Our evaluation was done with mixed fish samples in terms of several individuals used in one slide and revealed a small amount of analyzable metaphases, which limits statistical assessment of the results. We can only conclude that there is an impact of microcystins and cyanobacterial extract on the cytogenetic alterations of chromosomes. In further studies it would be desirable to use methods focused on other markers of genotoxicity, for instance leukocyte culture technique, sister chromatid exchange technique or micronuclei test. It is also not clear whether chromosomal alterations influence further development of fish. A ring chromosome usually contains all the necessary genetic material, and it is thus compatible with the survival. Dicentric chromosomes may pass through cell division without problems, however, they often result in dicentric budges at anaphase when the centromeres are pulled to opposite poles. A dicentric chromosome may be produced when two chromosomes with broken ends fuse. The acentric chromosome may be lost (Al-Sabti 1991).

In conclusion, crude extract of cyanobacteria caused higher mortality and changes in the development and behavior of exposed specimen than microcystins. Most probably, other toxic components present in the extract, not only microcystins, play a role in general toxicity. Increased chromosomal aberrations show cytogenetic effects of cyanobacterial extracts and this pilot study indicate that effects seem to be dependent on the amount of microcystins.

\section{Chromozomální aberace u raných stádií piskoře pruhovaného \\ (Misgurnus fossilis L.) vystaveného působení extraktu sinic a semipurifikované směsi microcystinů - pilotní studie}

Pomocí detekce chromozomálních aberací u raných stádií piskoře pruhovaného jsme zkoumali genotoxicitu semipurifikované směsi microcystinů a extraktu sinic. Jikry ve stadiu očních bodů byly po dobu $96 \mathrm{~h}$ exponovány semipurifikované směsi microcystinů (MC$\mathrm{LR}: \mathrm{SMC}=1: 2.6)$ a extraktu sinic (MC-LR: $\mathrm{SMC}=1: 2.1) \mathrm{v}$ dávkách 130, 50 a $13 \mathrm{mg} \cdot \mathrm{l}^{-1}$. U jednotlivých skupin jsme sledovali dobu kulení, změny v chování vykulených jedinců, kumulativní mortalitu a výskyt deformovaných jedinců. Dále bylo prováděno histologické a cytogenetické sledování. Kumulativní mortalita (28 a 26\%) vzrostla po aplikaci dávek 130 a $50 \mathrm{mg} \cdot \mathrm{l}^{-1}$ extraktu sinic $(p \leq 0.05)$. Vykulená embrya vykazovala $\mathrm{v}$ těchto skupinách sníženou pohyblivost, zůstávala ve shlucích a ve skupině vystavené nejvyšší koncentraci sinicového extraktu se objevily bílé tečky na žloutkových váčcích. Cytogenetickým vyšetřením jsme detekovali přítomnost jak chromatidových (gapy), tak chromosomálních aberací (kruhové chromosomy, dicentrické chromosomy), jejich procentické zastoupení 
se zvyšovalo v závislosti na koncentraci použitých látek. Nejvyšší počet aberantních metafází jsme nalezli u skupiny po aplikaci nejvyšších koncentrací extraktu i microcystinů $(p \leq 0.05)$. Embryonální mortalita byla ovlivněna zejména cyanobakteriálním extraktem, na této mortalitě se podílely pravděpodobně i jiné složky prrítomné v extraktu sinic.

\section{Acknowledgements}

This study was supported by the Research Project of the Ministry of Education, Youth and Sports of the Czech Republic: "Veterinary Aspects of Food Safety and Quality" (MSM 62 15712402).

\section{References}

AL-SABTI K 1991: Handbook of genotoxic effects and fish chromosomes Ljubljana, September 1991, p. 221

AMANUMA K, TAKEDA H, ANAMUNA H, AOKI Y 2000: Transgenic zebrafish for detecting mutations caused by compounds in aquatic environments. Nat Biotechnol 18: 62-65

BEST JH, EDDY FB, CODD GA 2001: Effects of purified microcystin-LR and cell extracts of Microcystis strains PCC 7813 and CYA 43 on cardiac function in brown trout (Salmo trutta) alevins. Fish Physiol Biochem 24: $171-178$

BOUAÏCHA N, MAATOUK I, PLESSIS MJ, PÉRIN F 2005. Genotoxic potential of microcystin-LR and nodularin in vitro in primary cultured rat hepatocytes and in vivo in rat liver. Environ Toxicol 20: 341-347

ČSN EN ISO 7346-2 1999: Water quality - Determination of the acute lethal toxicity of substances to a freshwater fish [Brachydanio rerio Hamilton-Buchanan (Teleostei, Cyprinidae)] - Part 2: Semi-static method. (In Czech)

DIEKMANN M, HULTSCH V, NAGEL R 2004: On the relevance of genotoxicity for fish populations I: effects of a model genotoxicant on zebrafish (Danio danio) in a complete life-cycle test. Aquat Toxicol 68: 13-26

DING WX, SHEN HM, ZHU HG, LEE BL, ONG CHN 1999: Genotoxicity of microcystic cyanobacteria extract of a water source in China. Mutat Res-Gen Tox En 442: 69-77

FESSARD V, BERNARD C 2003. Cell alterations but no DNA strand breaks induced in vitro by cylindrospermopsin in CHO K1 cells. Environ Toxicol 18: 353-359

HAYASHI M, UEDA T, UYENO K, WADA K, KINAE N, SAOTOME K, TANAKA N, TAKAI A, SASAKI YF, ASANO N, SOFUNI T, OJIMA Y 1998: Development of genotoxicity assay systems that use aquatic organisms. Mutat Res-Fund Mol M 399: 125-133

HOSE JE, BROWN ED 1998: Field applications of the piscine anaphase aberration test: lessons from the Exxon Valdes oil spill. Mutat Res-Fund Mol M 399: 167-178

HUMPAGE AR, FENECH M, THOMAS P, FALCONER IR 2000: Micronucleus induction and chromosome loss in transformed human white cells indicate clastogenic and aneugenic action of the cyanobacterial toxin, cylindrospermopsin. Mutat Res-Gen Tox En 472: 155-161

LANKOFF A, BANASIK A, OBE G, DEPERAS M, KUZMINSKI K, TARZYNSKA M, JURCZAK T, WOJCIK A 2003: Effect of microcystin-LR and cyanobacterial extract from Polish reservoir of drinking water on cell cycle progression, mitotic spindle, and apoptosis in CHO-K1 cells. Toxicol Appl Pharmacol 189: 204-213

LANKOFF A, KRZOWSKI L, GLAB J, BANASIK A, LISOWSKA H, KUSZEWSKI T, GOZDZ S, WOJCIK A 2004: DNA damage and repair in human peripheral blood lymphocytes following treatment with microcystinLR. Mutat Res-Gen Tox En 599: 131-142

LANKOFF A, WOJCIK A, FESSARD V, MERILUOTO J 2006: Nodularin-induced genotoxicity following oxidative DNA damage and aneuploidy in HepG2 cells. Toxicol Lett 164: 239-248

LIU Y, SONG L, LI X, LIU T 2002: The toxic effects of microcystin-LR on embryo-larval and juvenile development of loach, Misgurnus mizolepis Gunthe. Toxicon 40: 395-399

MANKIEWICZ J, WALTER Z, TARCZYNSKA M, PALYVODA O, WOJTYSIAK-STANIASZCZYK M, ZALEVSKI M 2002: Genotoxicity of cyanobacterial extracts containing microcystins from Polish water reservoirs as determined by SOS chromotest and Comet assay. Environ Toxicol 17: 341-350

MATOUŠKOVÁ O, CHALUPA J, CÍGLER M, HRUŠKA K 1992: Statistic system STATplus, version 1,01, book of reference. Veterinary Research Institute, Brno, 1992, p.168 (In Czech)

PIETSCH C, WIEGAND C 2001: The effects of a cyanobacterial crude extract on different aquatic organisms: Evidence for cyanobacterial toxin modulating factors. Environ Toxicol 16: 535-542

RÁB P, BOHLEN J, RÁBOVÁ M, FLAJŠHANS M, KALOUS L 2006: Cytogenetics as a tool in fish conservation: the present situation in Europe. In: Fish Cytogenetics. Eds: E. Pisano, C. Ozouf-Costaz, F. Foresti \& B. G. Kapoor. Science Publisher, Enfield, USA

RAO LPV, BHATTACHARYA R 1996: The cyanobacterial toxin microcystin-LR induced DNA damage in mouse liver in vivo. Toxicology 114: 29-36

RAO LPV, BHATTACHARYA R, PARIDA MM, JANAAM, BHASKAR ASB 1998: Freshwater cyanobacterium Microcystis aeruginosa (UTEX 2385) induced DNA damage in vivo and in vitro. Environ Toxicol Pharmacol 5: $1-6$

SHEN X, LAM PKS, SHAW GR, WICKRAMASINGHE W 2002: Genotoxicity investigation of a cyanobacterial toxin, cylindrospermopsin. Short communication. Toxicon 40: 1499-1501 
ZHAN L, SAKAMOTO H, SAKURABA M, WU DS, ZHANG LS, SUZUKI T, HAYASHI M, HONMA M 2004: Genotoxicity of microcystin-LR in human lymphoblastoid TK6 cells. Mutat Res-Gen Tox En 557: 1-6

ŽEGURA B, SEDMAK B, FILIPIČ M 2003: Microcystin-LR induces oxidative DNA damage in human hepatoma cell line HepG2. Toxicon 41: 41-48 
Plate I

Palíková M. et al.: Chromosomal ... pp. S53-S60
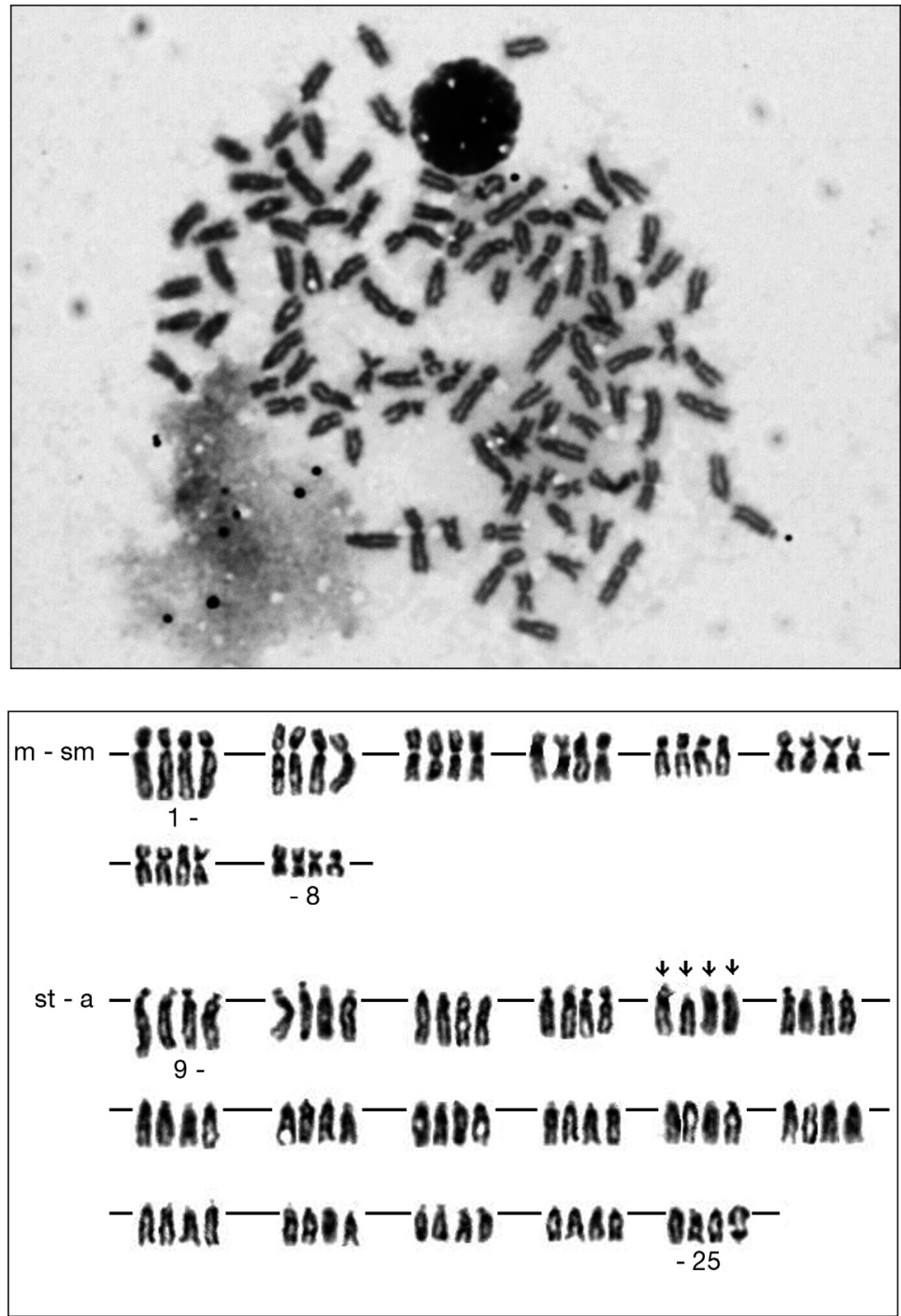

Fig. 1. Metaphase cell (above) and corresponding standard karyotype (below) of weatherfish with $2 \mathrm{n}=100$ chromosomes; m-sm: metacentric and submetacentric, st-a: subtelocentric and acrocentric chromosomes. 

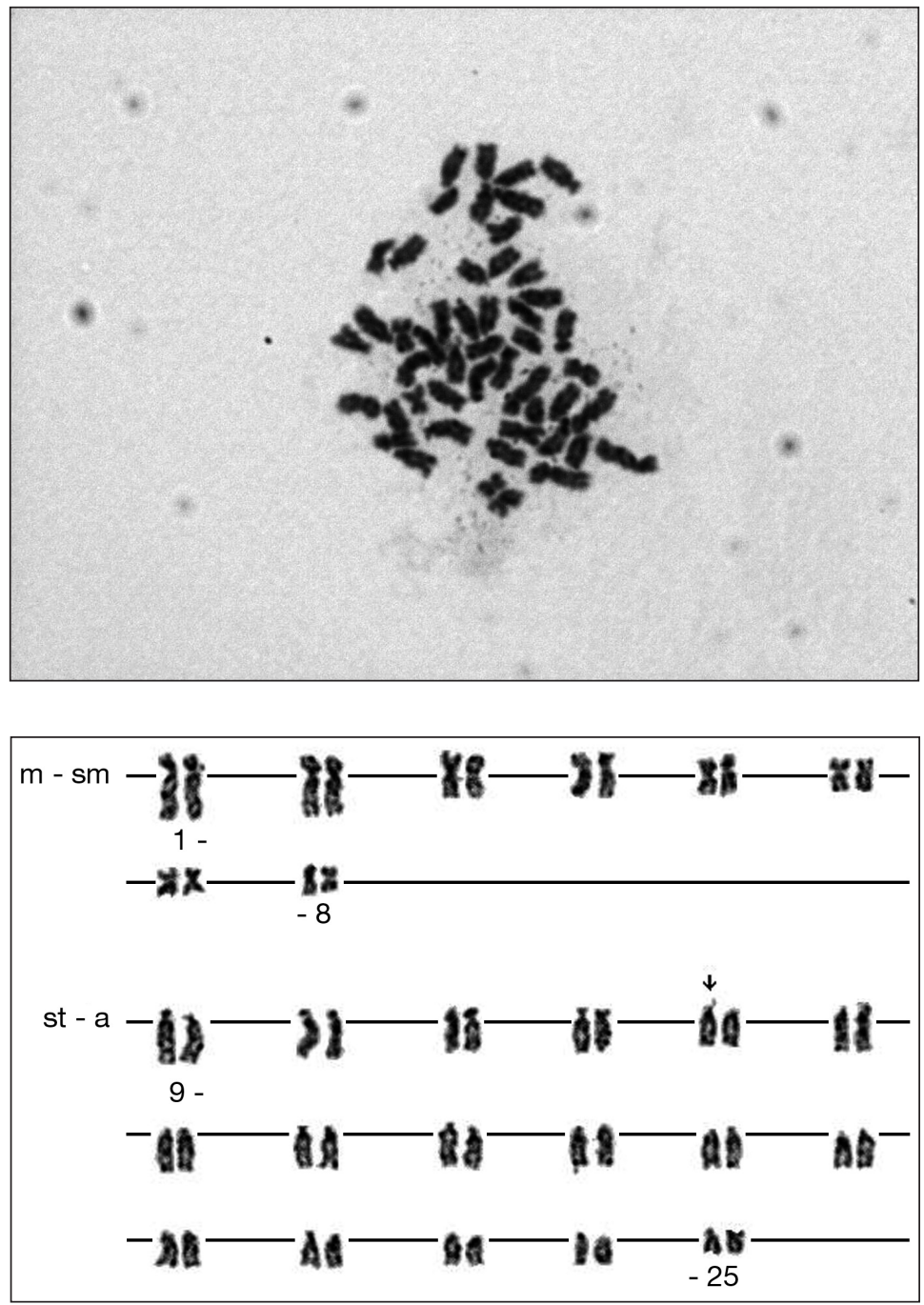

Fig. 2. Metaphase cell (above) and corresponding standard karyotype (below) of weatherfish with $2 \mathrm{n}=50$ chromosomes; m-sm: metacentric and submetacentric, st-a: subtelocentric and acrocentric chromosomes. 

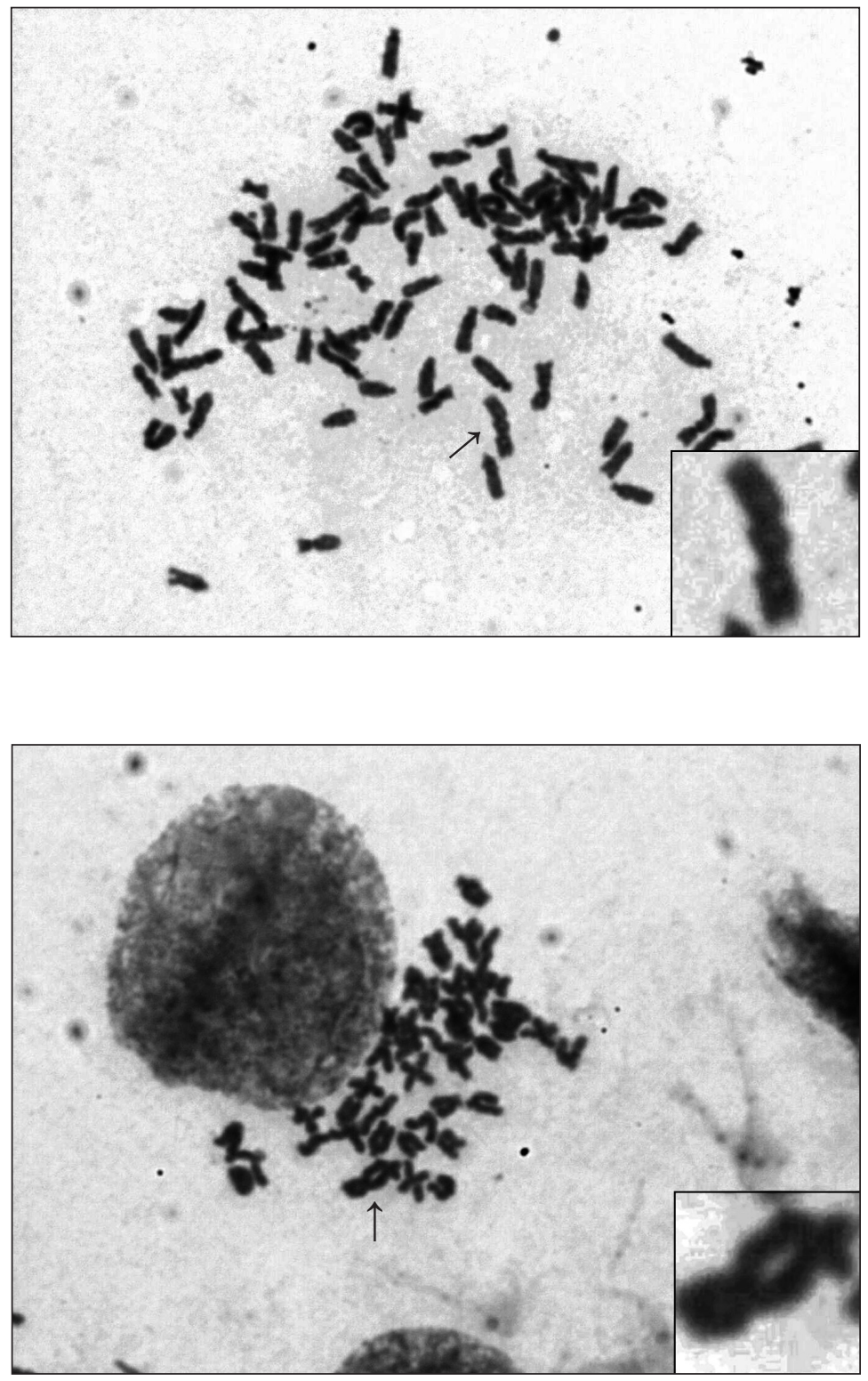

Fig. 3. Aberrant metaphases from group MC 50 (above) and E 13 (below), respectively. Dicentric chromosomes are shown by arrows. 
Plate IV

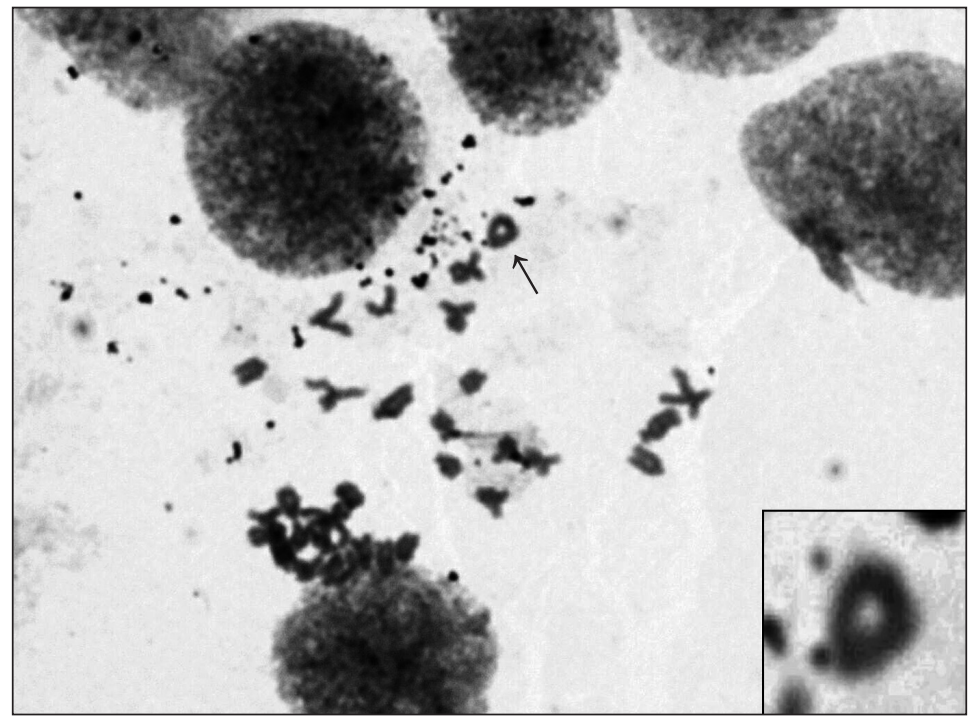

Fig. 4. Aberrant metaphase from group MC 13. Ring chromosome is shown by arrow. 